\title{
Comparative study of efficacy of Enalapril and Enalapril with Losartan in the management of Heart Failure
}

\author{
Dr.Zaheda Bano M.D ${ }^{1}$, Dr .Naga Jyothi Janapati M.D ${ }^{2}$ \\ ${ }^{I}$ (Prof \& HOD, Dept of Pharmacology, Guntur Medical College, Guntur,India) \\ ${ }^{2}$ (Yolkshire, London, U.K. )
}

\begin{abstract}
Heart failure is one of the most common causes of death and disability encountered in clinical practice. Recently animal studies and clinical trials demonstrated additional benefits following the addition of an Angiotensin receptor blocker to existing Angiotensin converting enzyme inhibitor.

It was a comparative randomized study performed on 100 patients admitted in cardiology Department, Government General Hospital, and Guntur.

The study comprised of 6 weeks period for each patient .50 patients were under Enalapril and 50 patients were under combination of Enalapril and Losartan. Before and after 6 weeks, Blood studie,E.C.G,Chest x ray, 2D echo were done.Patients were monitored for relief of symptoms, change in blood pressure and adverse effects. Results were tabulated, unpaired students ' $t$ ' test was done and $p$ values were calculated .Results were shown graphically also.The combination therapy improved the symptoms, ejection fraction $(P<0.001)$ and increased serum potassium significantly. $(P<0.05)$. So,the present study showed that combination therapy (Enalapril plus losartan) had better efficacy than Enalapril alone in the management of congestive cardiac failure.
\end{abstract}

Keywords: Losartan ,Enalapril ,Congestive Heart Failure

\section{Introduction:}

Heart failure is one of the most common causes of death and disability encountered In clinical practice. Recent animal studies and clinical trials demonstrated additional benefits following the addition of angiotensin receptor blockers to existing angiotensin converting enzyme inhibitors. ${ }^{(1)}$

\section{Headings:}

1. AIMS: To study and compare the effect and safety of enalapril with combination of enlapril and losartan and to study the ventricular function, improvement in the quality of life and to compare the tolerability.

\section{DRUGS:}

\subsection{ENALAPRIL: ${ }^{(5,6,7)}$}

It is a prodrug converted by hydrolysis to enalaprilat.

Plasma $\mathrm{T}_{1 / 2} 11 \mathrm{hrs}$

Protein binding: 50-60\%

Mainly eliminated through renal excretion

It inhibits angiotensin converting enzyme .

useful in hypertension left ventricular dysfunction and heart failure

Main adverse effects are hypotension ,cough, hyperkalemia

Dose : 2.5-20mg oral

\subsection{Losartan $^{(5,6,8)}$ :}

It is a selective non peptide AT- ${ }^{(2,3)}$ receptor antagonist.

It has 33 percent oral bioavailability.

Protein biding $98.7 \%$

Eliminated by both fecal and renal routes.

Used in Hypertension, Diabetic nephropathy, Heart failure

Adverse effects: Angioedema, Electrolyte imbalance, Impaired renal function

Dose 25-100mg. oral

\section{Methodology:}

It was a comparative randomized trail performed on 100 patients admitted in cardiology department .Government General Hospital, Guntur, India. 
Before study ethical committee approval and written informed consent in local language was obtained from each patient

\subsection{Inclusion criteria:}

stable heart failure of ischemic etiology ${ }^{(4)}$

Heart failure of NYHA Functional class III-IV

Resting left ventricular ejection fraction of less than $40 \%$

\section{2 .Exclusion criteria:}

Hepatic and renal failure,

COPD

Serum creatinine $<3 \mathrm{mmol} / 1$

Serum potassium $<5.5 \mathrm{mmol} / 1$

50 patients were under enalapril as monotherapy and 50 were under the combination of enalapril and losartan .The study was comprised of 6 weeks for each patient .They were given enalapril 5,10,20 mg per day and enalapril plus losaratan $2.5 . / 12.5,5 / 25,10 / 50 \mathrm{mg}$ for $1^{\text {st }} 2^{\text {nd }}$ and $3^{\text {rd }}$ week respectively.

$20 \mathrm{mg}$ per day for enalapril and 10/50 mg per day for combination therapy were maintained in each group for next 3 weeks. Before and after 6 weeks of treatment blood urea, serum creatinine, serum electrolytes, serum cholesterol, ECG, chest $\mathrm{x}$ ray and 2D echo were done.

Patients were monitored for relief of symptoms. change in blood pressure and adverse effects results were tabulated

Unpaired student's $\mathrm{T}$ test was done and $\mathrm{P}$ values were calculated

Results were shown graphically also.

\section{Results:}

In the enalapril group, the mean (S.D) ejection fraction before treatment was 35.36 (4.55) and after treatment, it was 36.28 (5.31) where as in the enalapril and losartan combination group.

The mean S.D ejection fraction before treatment was 35.06 (4.71) and after treatment it was 41.18 (4/50). So, there was significant improvement $(\mathrm{p}<0.001)$ in the ejection fraction in the combination group. On the other hand intergroup comparison reveals a superior effect of enalapril and losartan over enalapril with $(p>0.001)$. Patients with high risk factors like hypertension, hyperlipidemia, alcohol and smoking there is significant ( $\mathrm{p}<$ $0.05)$ improvement in the ejection fraction in the combination group.

There was a greater fall in systolic B.P in combination group $(\mathrm{p}$ value $<0.01)$ than enalapril

$(\mathrm{P}<0.05)$ and the combination group significantly decreases the diastolic blood pressure

$(P<0.001)$ than enalapril $(\mathrm{p}<0.01)$. There was a significant increase in the serum potassium $(P<0.05)$ in the combination group.

In the combination group patients showed much better clinical improvement in the symptoms. 24 patients in the combination group complained about cough where are 26 patients in single group complained about cough.

\section{Conclusion:}

The combination group improved the cardiac functions, systolic blood pressure, diastolic blood pressure and increases the serum potassium levels significantly than single group i.e, enalapril alone in C.C.F patients. As it was a combination therapy because of lower doses incidence of cough was less than in the combination group. So, it would be appropriate to perform the larger trials to confirm the clinical outcomes.

\section{Acknowledgements:}

My sincere acknowledgments to all my professors, helpers of drug companies and particularly to my patients

\section{References:}

[1]. Marc S Weinburg, Adam J. einburg, ion H Zap - effectively targeting the rennin angiotensin - aldosterone system in cardiovascular and renal disease; rationale for using angiotensin II receptor blockers in combination with angiotensin - converting enzyme inhibitors - JRAAS $2000: 1 ; 217-33$.

[2]. M Burnier, H.R. Brunner - angiotensin iireceptor antagonists - lancet 2000; 355:637-45.

[3]. Dr. D Rama Rao - Renin - Angiotensin - Aldosterone system in congestive cardiac failure - medicine update 2002; chapter 10; page

[4]. Gary S. Francis, John P. Gassler, Edmund H. Sonnenblick Pathophysiology and Diagnosis of Heart failure Hurst's the Heart text book: Vol-1, $10^{\text {th }}$ edition, chapter 20; page $-655 ; 657,658,678,679,692$.

[5]. Edwin K. Jackson - RENIN AANNGIOTENSIN from Goodman and Gillman's The Pharmacological basics of Therapeutics - 10 edition, chapter 31, page:809-833

[6]. Marc Harrold Angiotensin converting enzyme inhibitors, Antagonists and Calcium Blockers - Part II Pharmacodynamic agents; chapter 23; page - 533-550. 
[7]. MERCK \& CO; Inc. West Point, PA 19486, USA - "VASOTEC" (Enalapril Maleate) - Drug information.

[8]. MERCK \& CO; Inc; Whitehouse station, NJ 0889, USA - 'COZAAR' (Losartan potassium) - Drug information.

Tables: 1.ENALAPRIL

\begin{tabular}{|l|l|l|}
\hline MEAN S.D & BEFORE & AFTER \\
\hline & $35.36+/-4.55$ & $36.28+/-5.31$ \\
\hline SIGMA $_{12}=4.94$ &
\end{tabular}

\section{SIGMA $_{12}=4.94$}

$\mathrm{T}=0.93$

$\mathrm{P}>0.05$

2. ENALAPRIL PLUS LOSARATAN\% OF EJECTION FRACTION

\begin{tabular}{|l|l|l|}
\hline MEAN S.D & BEFORE & AFTER \\
\hline & $35.06+/-4.71$ & $41.18+/-4.50$ \\
\hline
\end{tabular}

SIGMA $_{12}=4.60$

$\mathrm{T}=6.64$

$\mathrm{P}<0.001$

3. Comparison of percentage in patients with hypertension smoking + al=cohol; +hyperlipidemia after 6 weeks treatment

\begin{tabular}{|c|c|}
\hline $\mathrm{E}$ & $\mathrm{E}+\mathrm{L}$ \\
\hline MEAN S.D $33.6+/-3.66$ & $40.75+/-5.16$ \\
\hline
\end{tabular}

SIGMA $_{12}=4.57$

$\mathrm{T}=2.88$

$\mathrm{P}<0.05$

4. Comparison of ejection fraction percentage in patients with hypertension smoking +alcohol; +hyperlipidemia after 6 weeks treatment

\begin{tabular}{|c|c|}
\hline E & E+L \\
\hline MEAN S.D $38.91+/-2.18$ & $43+/-3.71$ \\
\hline
\end{tabular}

SIGMA $_{12}=3.23$

$\mathrm{T}=2.91$

$\mathrm{P}<0.05$

EJECTION FRACTION

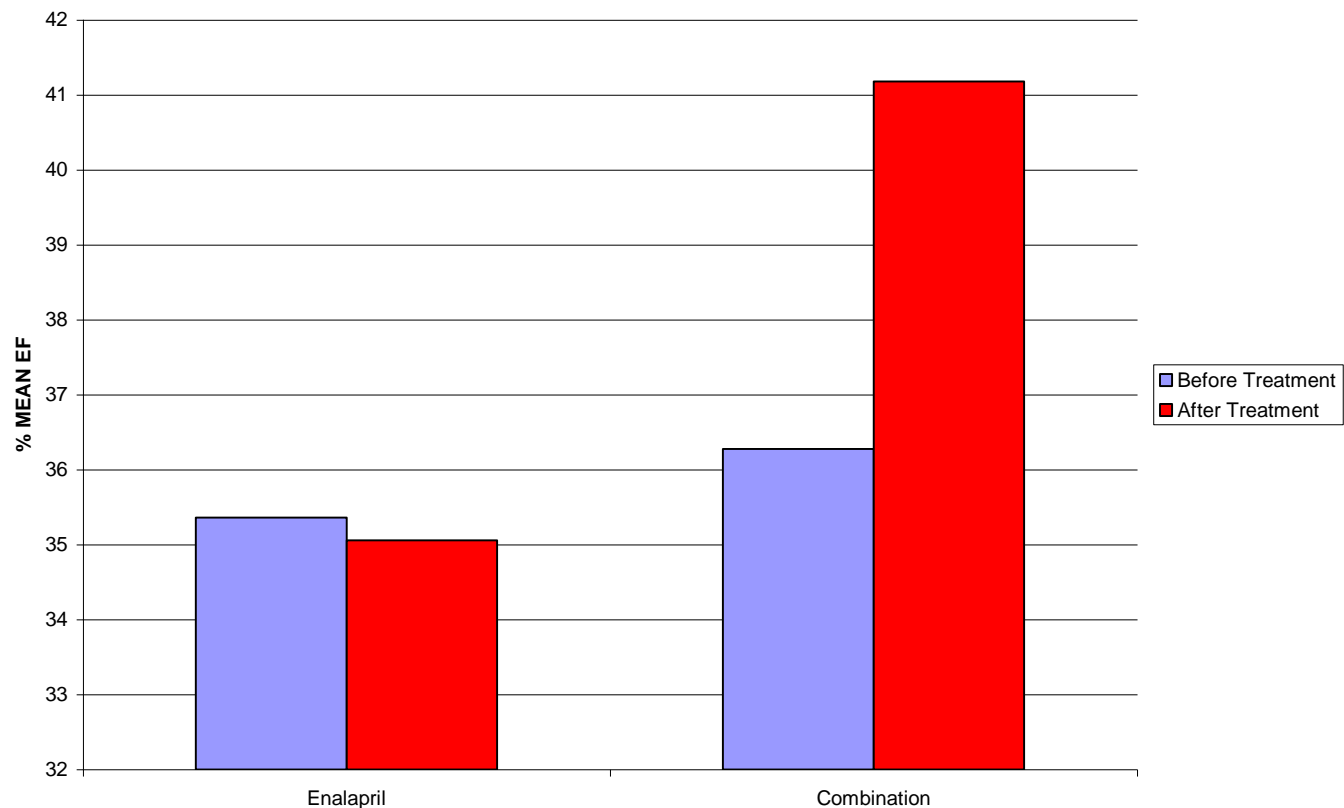


SYSTOLIC BLOOD PRESSURE

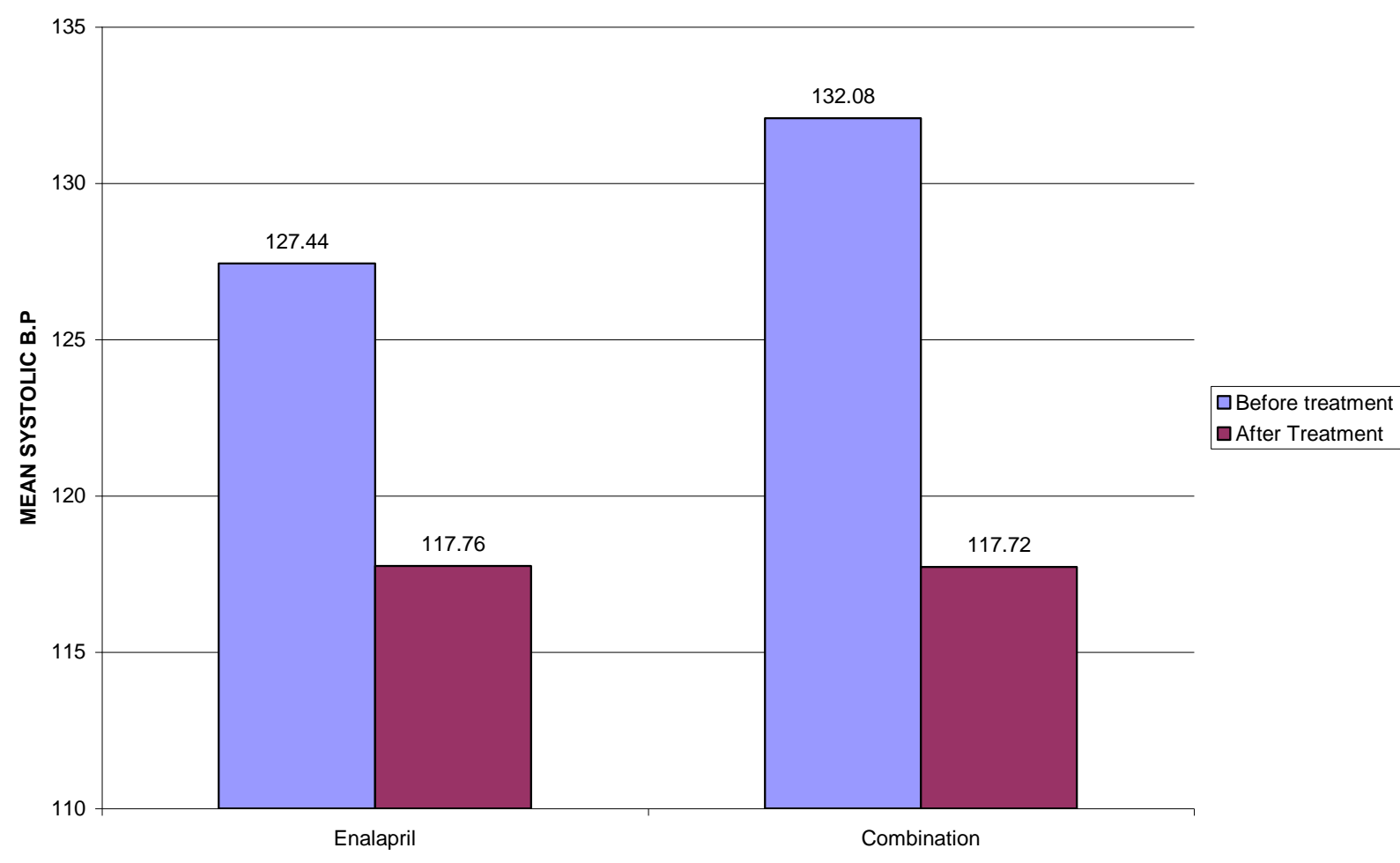

DIASTOLIC BLOOD PRESSURE

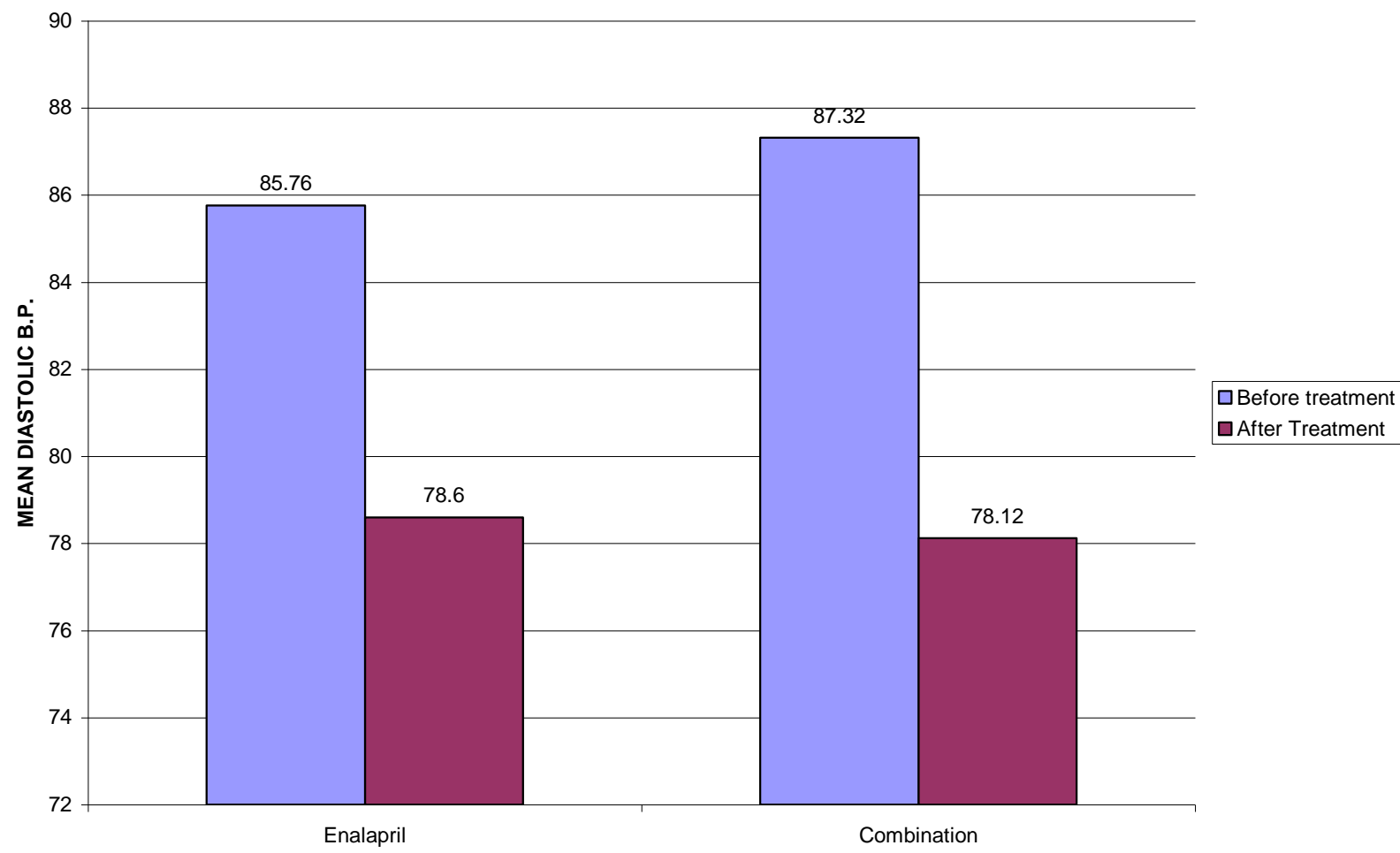


SERUM POTASSIUM

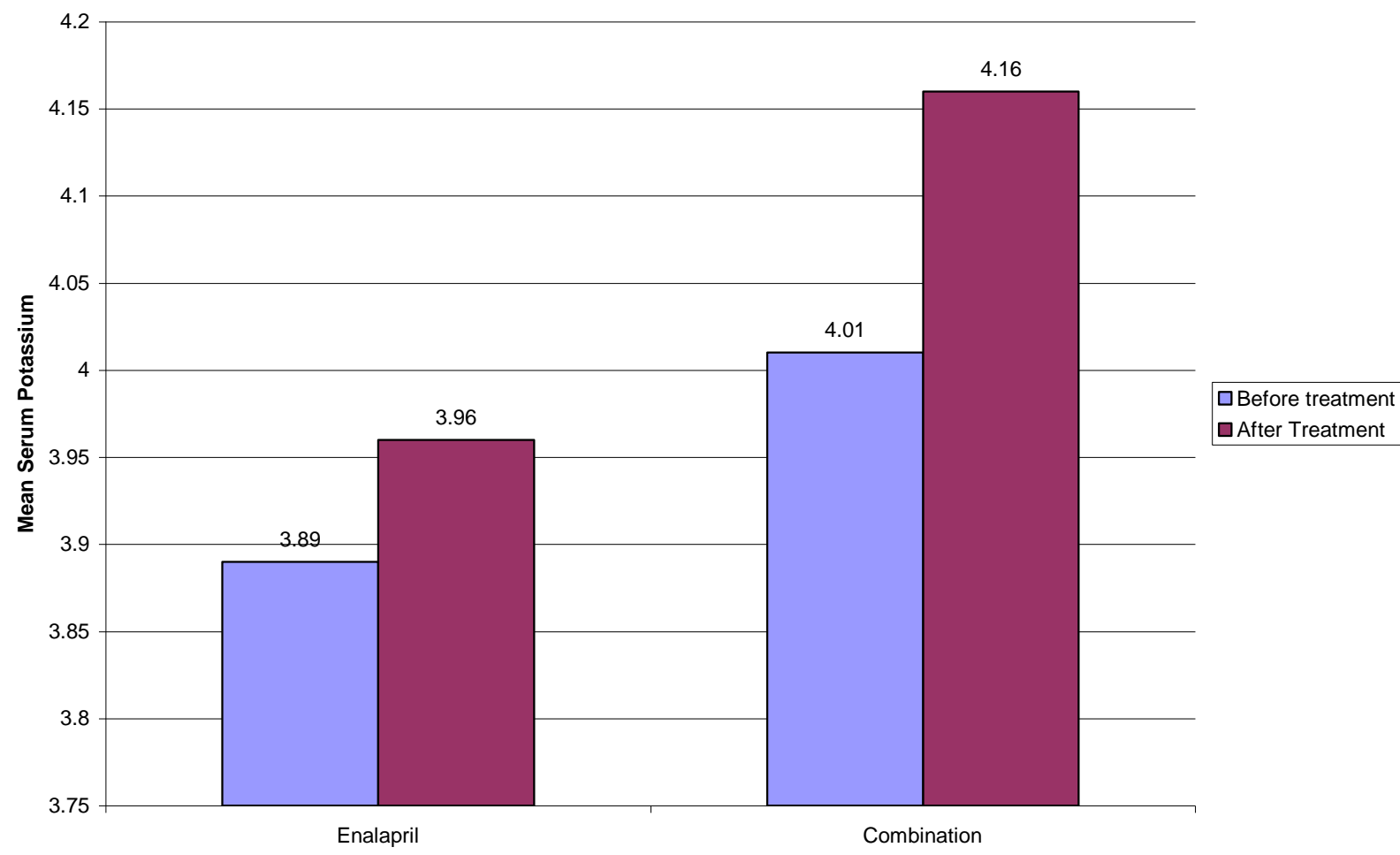

